\title{
Proclus' Elements of Theology and Platonic Dialectic
}

\author{
Jan Opsomer \\ KU Leuven* Internal Research Funds
}

Why did Proclus want to present his metaphysical system, that is, his and his colleagues' views on Platonic theology, in the manner of the geometers? Scholars have expressed widely diverging views on this question, and the fact that the Elements of Theology itself fails to provide us with any context certainly has not helped to settle the issue. This text, unique in its kind, indeed comes without paratext, and moreover, Proclus nowhere so much as mentions the Elements of Theology in his other works, let alone discusses its aims.

The most common assumption seems to be that Proclus adopted the mos geometricus for the clarity of exposition it makes possible, as it allows the author to focus on individual tenets and single principles or rules, discussing them one after another. These are ordered in such a way that later propositions are demonstrated on the basis of preceding ones so that the exact logical relations are made apparent. An even more generous interpretation would have it that the author, on the condition that one accepts the assumptions that serve as starting points and the arguments are valid, has been able to actually deduce the truth of the propositions.

With various qualifications, such views have been expressed by famous scholars. E.R. Dodds, for instance, calls the work "an attempt to supply the comprehensive scheme of reality desiderated by Plato in the seventh book of the Republic", giving us what earlier manuals failed to provide, namely "the general logical principles which form the structural skeleton of the system." "And it is nothing if not systematic", ${ }^{3}$ although Dodds admits that its "method of pure $a$

\footnotetext{
* Internal Research Funds / ERC Advanced Grant -885273-PlatoViaAristotle.

1 Dodds 1963, p. $x$.

2 Dodds 1963, p. ix.

3 Dodds 1963 , p. x.
}

(C) KONINKLIJKE BRILL NV, LEIDEN, THE NETHERLANDS, 2022 | DOI:10.1163/9789004501331_003 
priori deduction" is, at times, merely apparent. ${ }^{4}$ E.-O. Onnasch and B. Schomakkers take issue with Dodd's view that the Elements of Theology is to be seen as a Neoplatonic compendium, since, as they claim, Proclus has his own particular position in that tradition. They agree, however, with the general idea that the work expounds many fundamental tenets of Neoplatonic metaphysics. ${ }^{5}$ They confirm, moreover, that the proofs are formally rigorous and valid 6 while disputing the idea that Proclus has reached Spinoza's ideal of a closed logical system, or even laid claim to such an ideal ${ }^{7}$ (the latter remark pertaining to the possible axiomatic character of the Elements of Theology, an aspect that will not be discussed here). Linking this view with the work's lack of axiomaticity, these scholars claim that Proclus' goal is primarily didactic, and since the work does not present a logically closed system deduced from indubitable principles, it is merely didactic. It is a merely human and, thus, in some sense, an arbitrary attempt to disclose an epistemic domain. ${ }^{8}$

D. O'Meara ${ }^{9}$ is the author of a different and influential interpretation, according to which Proclus does not really use the geometric demonstrative method, but instead choses certain aspects of the 'geometric' format for the clarity of exposition and the logical rigour it allows for presenting his views. Geometry, by this account, exemplifies the discursive type of reasoning of science, not of the higher 'dialectic' - a distinction famously made by Plato, Resp. VI 510b-511d.

An unusual interpretation is proposed by J.-L. Solère, ${ }^{10}$ according to which Proclus uses the geometric method in order to make Platonic doctrine less accessible, hiding it from the masses whose mathematical knowledge is very limited. Solère, however, must admit, that the evidence is based on sources that have nothing to do with Proclus, primarily Boethius (Hebdom. sRT p. 38.8-14) and the tradition dependent upon him. There is, however, some supporting evidence for this view from a source closer to Proclus. His student and biographer Marinus quoted him as saying at the end of what could be called his hagiography that, if it were up to him, of all the ancient books, he would only preserve the Timaeus and the (Chaldean) Oracles, because the others, if they are read

Dodds 1963, p. xi.

Onnasch and Schomakers 2015, p. XLV.

Onnasch and Schomakers 2015, p. XLVI.

Onnasch and Schomakers 2015, p. XLIX.

Onnasch and Schomakers 2015, p. LII-LIII.

O'Meara 200o, p. 285-286; O'Meara 1989, p. 196-198.

10 Solère 2003. A remark that goes in the direction of Solère's thesis can be found in Dodds 1963, p. xiii. 
in a careless and uneducated manner, are likely to do more harm than good." Even if these presumably authentic words do not pertain to Proclus' own books, they do testify to a certain mind-set that would support Solère's interpretation. Moreover, Proclus confirms in his own work the idea that a theological science such as dialectic may be difficult to grasp for the untrained, or for those who are unwilling or unable to go through the required efforts, creating confusion in their minds. ${ }^{12}$ Still, in the light of his other work, it is hard to defend the idea that Proclus is after secrecy. Take, for instance, the quite accessible Tria opuscula, or the Elements of Physics, another work written in the same spirit and dealing with physical matters. Solère's claim also goes counter to the idea at the core of the literary genre in question, that is, providing elementary, manageable instruction for the uninitiated. 'Elementary' means, as I shall argue, that the work is meant to provide the most fundamental tenets, which are the simplest and, at the same time, the most basic.

One idea that the aforementioned interpretations have in common is that the work is intended to convey an impression of logical rigour with the ulterior goal of convincing its audience of the truth of the doctrines exposed. The work would thus contain an implicit claim to epistemic authority. Recently, however, Reviel Netz ${ }^{13}$ has contested the idea that the literary genre of treatises written more geometrico possessed the same degree of authority that we are inclined to attribute to them. The genre that goes by the name of Elements ( $\sigma \tau \circ \chi \chi \varepsilon i \alpha)$ or, in Proclus' case, Elementatio ( $\sigma \tau \circ \chi \chi^{2}(\omega \sigma / \varsigma)$, is that of rudimentary handbooks intended for novices. If certain proofs appear difficult in Euclid, and, by extension, in Proclus, the problem lies with us, not the proofs themselves: we may find them hard to follow, and their logic may elude $u s$, but this is a result of particular developments in cognitive history. ${ }^{14}$ However, that readers closer in time and cultural environment to Proclus were impressed by the logical rigour of the work speaks against Netz's thesis. The work and the genre did indeed seem to enjoy a high epistemic authority. Nicholas of Methone, a Byzantine reader, warns against the danger presented by the work's semblance of logical rigour, ${ }^{15}$ and whereas Nicholas, despite implicitly admitting the logical strength

\footnotetext{
11 Marinus, Vita Procli 38, p. 44, 1. 17-20.

12 In Parm. V, 1024.2-1025.3 (for the line numbers of In Parm., I use the oct edition by Steel et al.). See also Fauquier 2018, p. 109.

13 Netz 2017.

14 Netz 1999, p. 1-7.

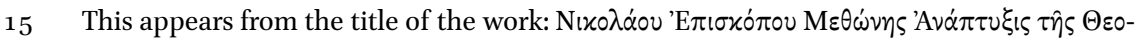

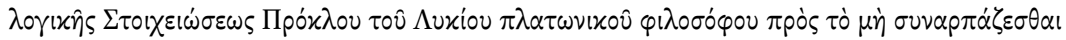

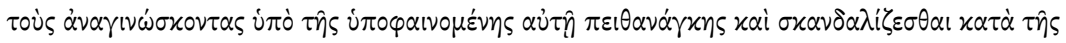


of the work, remained ultimately unconvinced, his contemporary Ioane Petritsi was truly impressed by its logical quality, ${ }^{16}$ and in the West, Berthold of Moosburg praised the demonstrative qualities of the text and its genre. ${ }^{17}$ Later, the humanist Francisco Patrizi presented both the Elements of Physics and the Elements of Theology as paradigms of argumentative precision for his readers to imitate. ${ }^{18}$ These testimonies, however, do not in themselves constitute strong counter-evidence to Netz's claim. Therefore, in order to examine the intended epistemic status of the text, as well as to possibly gain a better understanding regarding its intended readership, I propose that we search for clues in Proclus' own works.

\section{$2 \quad$ Platonic Dialectic}

There has been some discussion over the question of whether, and in what sense, Proclus' Elements of Theology presents an axiomatic system. This issue, complicated by various existing conceptions of what it means to be axiomatic, is not one which will be pursued here. ${ }^{19}$ Whereas the highly philosophically relevant question regarding axiomatics is not posed in Proclus' own terms, I shall here ask a related question aimed at the way in which Proclus himself

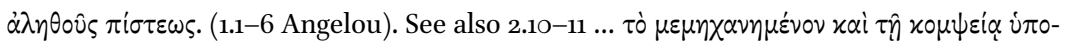

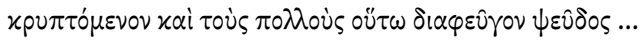

16 Cf. Ioane Petritzi, In Elementationem theologicam, prologue, Alexidze and Bergemann 2009, p. 63 .

17 Berthold of Moosburg, Expositio super Elementationem theologicam, prol., 349-364 tit. K, p. 47 .

18 Patrizi, Procli Lycii Diadochi philosophi eminentissimi Elementa theologica, p. 4: Verum ad Proclum redeamus. Cuius Elementa theologica tibi Parolari eruditissime animo libenti damus. Uti cognoscas, quanto ingenii acumine mathematico more, Theologia Platonis universa mira demonstrationum necessitate sit demonstrata. Addita sunt physica quoque Elementa, ex Aristotelis dogmatibus desumpta, eodemque modo tradita: quo modo, res nulla alia quam mathematica, a quoquam unquam alio, est tractata: et quae suo hoc exemplo sublimium philosophorum ingenia in reliquis philosophiae partibus movere queat ad imitandum.

19 O'Meara 200o, p. 285-286, in agreement with Lowry 1980, Lohr 1986, p. 59-6o, and already Dodds 1963, p. xi-xii, argues that, contrary to appearances, Proclus' method is not strictly speaking axiomatic. Netz 2017 agrees with O'Meara on the crucial point that the work does not seem to rely purely on the structure of axiomatic derivation. The main reason is that Proclus brings in extra assumptions for the sake of some individual arguments. Martijn 2014, p. 151-153 challenges this received view, whose main advocate is O'Meara: starting from an analysis in Opsomer 2013, she claims that Proclus' method is, after all, essentially geometrical and even axiomatic. I intend to discuss this issue elsewhere. 
was likely to have conceptualised his undertaking. This is the question regarding the relation between the Elements of Theology and Platonic dialectic. I shall indeed argue that not only could Proclus regard this work as dialectic in nature, but that this is in fact what he probably intended the informed reader to understand.

As I have pointed out before, though the Elements of Theology comes without paratext, the very use of the genre to which it belongs should tell us something about the light in which it is to be read. The set of stylistic conventions that the genre of the geometric handbook comes with need not concern us here. ${ }^{20}$ More important, however, are its impersonal style and its lack of appeal to authority.

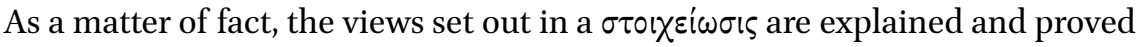
without any mention of their authors, and there is usually no place for alterna-

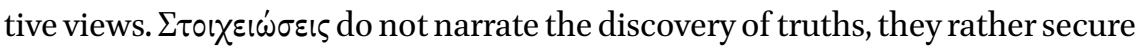
results. These works essentially consists of theorems and proofs, or, rather, of assumptions, theorems, and proofs, assumptions set out in the beginning of the work in the form of definitions, axioms, postulates, and common notions. ${ }^{21}$ One of the remarkable features of the Elements of Theology is that such lists are absent: the work immediately starts with the first theorem and its proof. Any interpretation of this work must account for this notable fact. The Elements of Physics differs in this respect, as it consists of two sets of theorems, or 'books', each of which is preceded by a list of definitions that contain assumptions needed for the proofs. One would have also expected, then, at least a list of stipulative definitions in the Elements of Theology as well. As we will see, the first arguments are largely based on the meaning of certain key terms, and the Commentary on Euclid shows that Proclus knows very well that definitions, in the geometric tradition, serve to introduce hypotheses, that is, undemonstrated presuppositions. ${ }^{22}$

20 I have discussed the genre and the way it is used by Proclus in the Elements of Physics and the Elements of Theology in Opsomer 2020. A more thorough treatment of the formal characteristics of the genre is offered by Asper 2007, p. 94-212.

21 Proclus distinguishes between axioms, hypotheses, and postulates: In Euclidem 76.4-77.6. An axiom is a first principle that is known to the learner and credible in itself. A hypothesis is not immediately self-evident, but is conceded. A postulate is unknown, taken as true, but without having been conceded by the student. Sometimes, however, these are all called hypotheses. See, for instance, In Euclidem 71.14-15; 178.1-184.10; Beierwaltes 1965, p. 262-265; Giardina 2010.

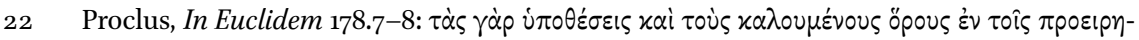

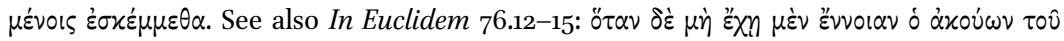


The Commentary on Euclid can shed more light on Proclus' understanding of the genre. Euclid's Elements are named after its primary constituents, that is, elements ( $\sigma \tau \circ \chi £ \varepsilon i \alpha) .{ }^{23}$ Elements, Proclus explains, are propositions that are fundamental for an epistemic domain, the knowledge of which can be used to solve problems and is needed to gain knowledge of other things within the same domain. They are like letters ( $\sigma \tau \circ \chi \varepsilon \hat{\varepsilon} \alpha)$ in written speech: the simplest, atomic and first principles. These leading theorems ( $\left.\theta \varepsilon \omega \rho \eta \dot{\mu} \mu \alpha \tau \alpha \pi \rho \eta^{\prime} \gamma \mathcal{u}^{\prime} \mu \varepsilon v \alpha\right)$ function as starting points from which the subsequent propositions are developed, being implicated in them all and providing the basis for demonstrations. Other propositions are called 'elementary' ( $\left.\sigma \tau 0 \chi \chi \varepsilon เ \iota^{\prime} \delta \eta\right)$. Like the elements, they are simple and elegant, but unlike the elements, they are not necessary for the

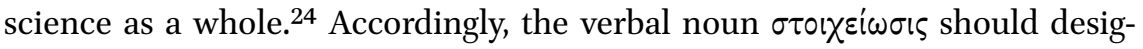
nate the systematic arrangement of an epistemic domain as a set of discrete propositions, ordered in such a way that later propositions are proved from the preceding ones (and the first propositions are proved from undemonstrable axioms). This ideally results in an irrefutable and complete system of propositions, which can rightly be called scientific. ${ }^{25}$

Proclus additionally refers to a further distinction made by a certain Menaechmus: in a more general sense the term 'element' stands for anything furnishing the proof. By this fact, it is the 'element' of that which is proved, and this wider usage allows for reciprocity. The more narrow use, by contrast, is asymmetric: if $A$ is an element of $B, A$ is prior to $B$ and $B$ cannot be an element of A. ${ }^{26}$ It is clear that Proclus adopts the narrow meaning in his explanation of

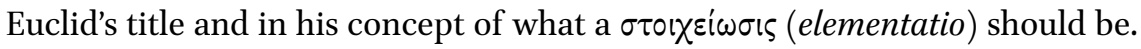
A true $\sigma \tau 0 \chi \chi \varepsilon i \omega \sigma \iota \varsigma$ presents the ideal structure of a science, ordered from simple to complex and linked through inferences. And for this very reason, it is the

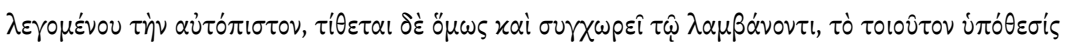

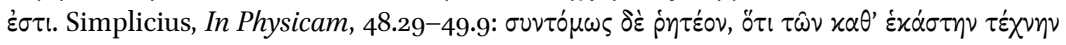

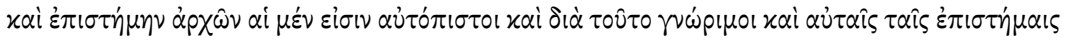

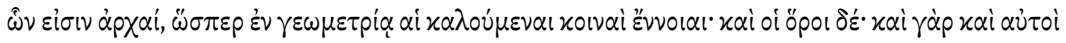

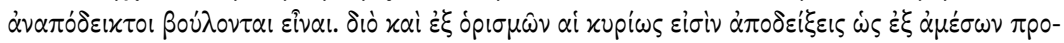

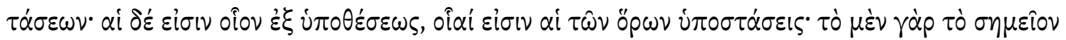

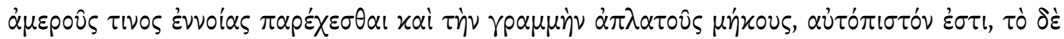

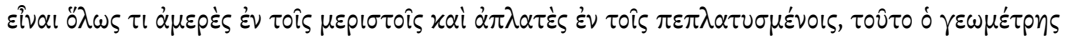

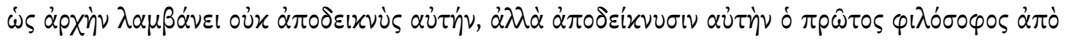

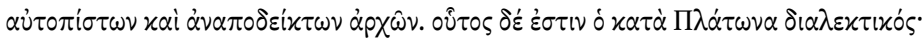

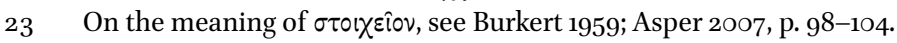

24 Proclus, In Euclidem, 71.24-72.19.

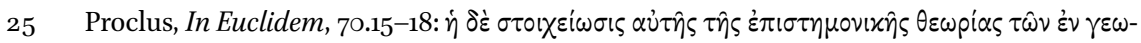

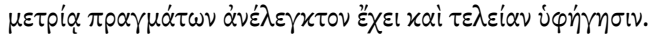

26 Proclus, In Euclidem, 72.23-73.9. 
perfect didactic tool. Furthermore, Proclus implies that it presents discoveries that may have been made by others, yet it is not used to make discoveries. It presents them while simultaneously making them incontrovertible, armoured by irrefutable proofs. ${ }^{27}$

A feature that remains implicit in Proclus' account of the genre but is deci-

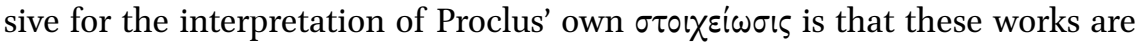
supposed to be self-contained. By this I mean that they are not supposed to appeal to other scientific knowledge that one may have acquired elsewhere, for instance, knowledge that is the fruit of exegesis (common notions pose a special problem, as we shall see). This is indeed what the reader can expect when she comes in contact with the Elements of Theology, though whether the work lives up to this expectation is a different matter. It is, however, essential for an appropriate understanding of the work, and especially of the crucial first propositions.

In the Commentary on Euclid, Proclus leaves no doubt whether he considers mathematics and its different branches to be sciences. What about the kind of theology he practices in the Elementatio? (For the present purpose, it makes no difference whether one prefers calling this discipline 'theology' or 'metaphysics,', ${ }^{28}$ in accordance with the present acceptation of that term). Proclus usually distinguishes the following levels of cognition proper to humans, in ascending order from irrational to rational: perception, imagination, doxa (which is already rational and is able to proceed without images), and science. Science ( $\left.\dot{\varepsilon} \pi \sigma \tau \eta^{\prime} \mu \eta\right)$ is truly rational; it belongs to logos, the rational capacity that is able to grasp forms. It is, however, only a preparation for the intellective contemplation of Forms. ${ }^{29}$ In other words, the list is not yet complete. Intellect grasps Forms all at once and without transitions. ${ }^{30}$ This means that contrary to logos, and hence also to science, it is no longer discursive. The Forms accessed by intellect are not identical to the formal principles grasped by the soul, as the latter are images of the former and are more precisely described as formal logoi ('formal reason principles'). ${ }^{31}$ Not even intellection is the highest form of cognition of which humans are capable, since higher than intellection is the unitary grasp of the Good, which can only be accomplished with the most divine capac-

\footnotetext{
27 Proclus, In Euclidem, 68.7-10.

28 Cf. O'Meara 1986.

29 Proclus, In Parmenidem, v, 994.27-995.4; 1026.21-28.

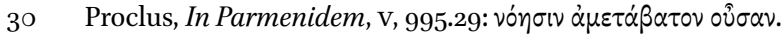

31 Proclus, In Parmenidem, v, 980.23-981.21; 982.7-24; cf. also IV, 896.2-3; 896.18-20.
} 
ity of the soul. ${ }^{32}$ For the issues at stake, however, we can restrict our scope to the levels of science and intellect.

Dialectic is the highest of sciences, the crowning and truest science. ${ }^{33}$ Yet it, too, is an image of the intellective cognition and derives its principles from there. ${ }^{34}$ It is moreover a preparation, an exercise with a view to intellective cognition. Although Proclus does not state this explicitly, I take him to mean it is an indispensable preparation for intellection. To that extent, and also because dialectic is the highest science, the term "exercise" ( $\gamma v \mu \nu \alpha \sigma i \alpha)$ is not necessarily used depreciatingly. The origin of the view of dialectic as being an exercise is, of course, Plato's Parmenides, where the older Parmenides urges the young Socrates to get himself some training before tackling the problems that as yet surpass him. ${ }^{35}$ This text, for Proclus, is essential to understanding the Platonic concept of dialectic, ${ }^{36}$ in combination with Plato's remarks in the sixth and seventh book of the Republic. ${ }^{37}$ Dialectic can thus be seen to be a mental training

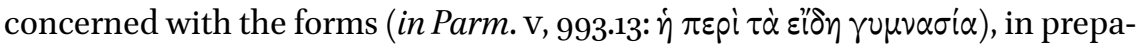
ration of intellective contemplation.

Proclus' description of dialectic as training seems to fit the Elements of Theology very well:

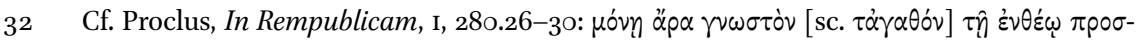

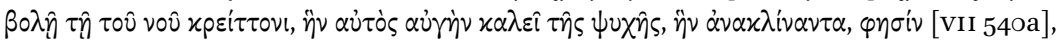

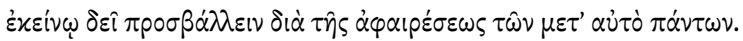

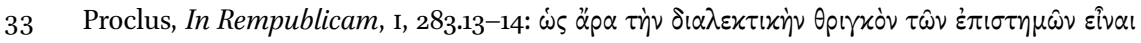

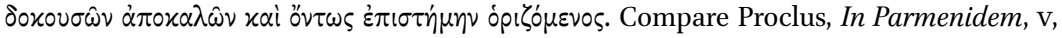
995.17-18 Steel. The source is Plato, Respublica, VII, 534e2. Platonic dialectic is to be distinguished from Aristotle's conception of dialectic, which is doxastic, not scientific. Cf. Proclus, In Parmenidem, v, 984.21-985.3; 989.1-23; 990.10-11; Theologia Platonica, I.9, 40.118; Fauquier 2018, p. 102-103.

34 See also Plotinus, Enneads, I.3 [20] 5.1-5. See Gourinat 2016, p. 39-41 for Plotinus' influence on Proclus' conception of dialectic.

35 Plato, Parmenides, $135 \mathrm{c} 8$; d7; 136c5. Interestingly, Zeno adds the remark that no one is able

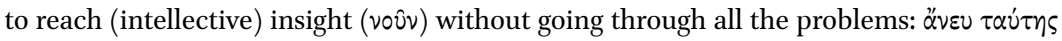

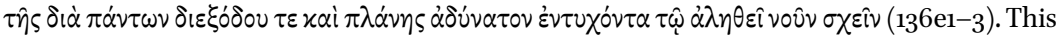

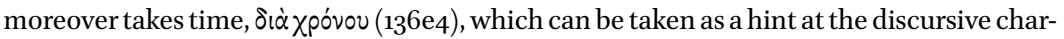
acter of dialectic. Cf. Proclus, In Parmenidem V, 1026.17-19 and In Rempublicam II, 19.15-16,

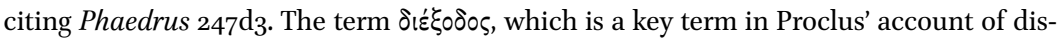

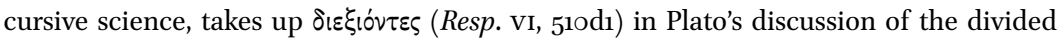
line.

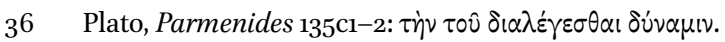

37 A further important passage is Sophist $253 \mathrm{~d} 2-\mathrm{e} 2$, where Plato calls dialectic a science capable of division along kinds and distinguishing sameness and difference between kinds. This passage is cited by Proclus, In Parmenidem, I, 650.2-9. 


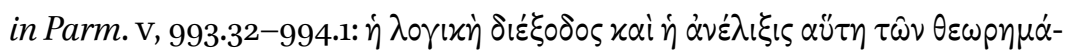

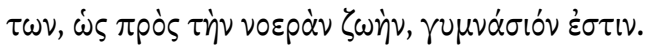

The whole of the logical procedure and this unfolding of theorems, in relation to intellectual life, is a field of exercise.

trans. G.R. MORROW-J. DILLON

In the Elements of Theology, theorems are indeed being unfolded discursively, that is, by being looked at them one by one along with the logical relations linking them. No longer making the transitions, but grasping all the logical relations as stable structures, the intellect, so Proclus believes, is able to grasp all of this at once.

Traditionally, Platonic dialectic was seen to comprise four methods: analysis, division, definition, and demonstration. This view was common in handbooks ${ }^{38}$ and was adopted by Proclus. ${ }^{39}$ But for him the four methods are not on a par with one another. As divisions deliver definitions, the art of division ${ }^{40}$ is superior to that of definitions, and definitions in turn are superior to demonstrations, in that the latter require the former. These three operations, moving from principles to effects, belong together (demonstrations prove essential accidents) and are contrasted with analysis, which moves from effects to principles. ${ }^{41}$ These operations or methods-powers, considered from the perspective of the soul performing them ${ }^{42}$ - can be discerned at work in the Elements of Theology.

More precisely, the dialectic we see at work here, which reveals the truth in its purity, would be the highest of the three, since Proclus also distinguishes three dialectical activities depending on the level of its practitioners and the corresponding aims to be pursued (in Parm., I, 653.4-656.10). ${ }^{43}$ In order to study the Forms, the dialectic uses the four standard methods, including those that move downward as well as analysis, which moves upward, and is able to ascend to the unhypothetical principle.

One could object here that, in fact, Proclus has a much more specific view of dialectic; namely, the one found in the second part of the Parmenides which is

38 Cf. Alcinous, Did. v. See also Kobusch 2018, p. 67-68.

39 Proclus, Theologia Platonica, I.9, 40.5-10; In Eucl. 69.13-19; In Parmenidem, v, 10o3.6-7. See also Syrianus, In Metaphysicam, $55 \cdot 38^{-56.4}$.

40 This art conforms to the first of the three types of definition mentioned by Proclus, In Cratylum, IX, 3.11-2O.

41 Proclus, In Parmenidem, v, 982.9-24, with Fauquier 2018, p. 118-120.

42 Bonelli 2016, p. 409 in this respect speaks of a "hesitation."

43 Steel 1997, p. 87-88; Gritti 2008, p. 177-184. 
based on the method of hypotheses. There is hardly a trace of this method in the Elements of Theology. This objection, however, can be discarded quite easily, as it is simply not the case that Proclus identifies ${ }^{44}$ dialectic with the procedure set out and exemplified in the Parmenides. Rather, the latter is a specific type of dialectic, explicitly called the Eleatic type of dialectic. ${ }^{45}$ The attempt to reduce the Parmenidean dialectic to the four traditional operations, C. Steel ${ }^{46}$ argues, is forced, and the same point could be made were we to do such a thing for the Elements of Theology. Fortunately, this is not necessary. It suffices to point out that some of the operations are being used in the course of the work in a way that is similar to what Proclus claims about Euclid.

Proclus indeed thinks that Euclid in his Elements makes more than an occasional use of dialectic, employing all four dialectical methods: "division for finding kinds, definitions for making statements of essential properties, demonstrations for proceeding from premises to conclusions, and analysis for passing in the reverse direction from conclusions to principles" (in Eucl. 69.13-19, trans. G.R. Morrow). This is a highly interesting claim, stemming from the so-called second prologue to the Commentary, if only because it shows that Proclus thinks that the mos geometricus and dialectic can be integrated, especially if the geometer in question also happens to be a Platonist, as is the case with Euclid (cf. in Eucl. 68.20-24). Moreover, this makes it highly likely that, on Proclus' understanding, the same could be said for the Elements of Theology, given the many formal similarities between the two works. In another passage, this time from the first prologue, Proclus, citing Plato's Republic, confirms the special relation between mathematics and dialectic, calling this purest part of philosophy the 'crown', or more literally, the 'capstone' 47 of the (mathematical) sciences $(42.9-44.24) .^{48}$ Because of the equivocity of the word $\mu \alpha \theta \dot{\eta} \mu \alpha \tau \alpha$, it is not really clear whether 'dialectic' is meant to be the capstone of all the sciences or pre-eminently, or even exclusively, of the mathematical sciences. However, given the context of the Commentary on Euclid, the primary reference in the passage would be mathematics. At any rate, the mathematical sciences, being the stepping-stones to dialectic, occupy a special place among the sciences. It is also nice to think that the relation between mathematics and dialectic is

\footnotetext{
44 Fauquier, 2018, p. 104, seems to imply that Proclus seeks to identify the two, but his view is actually more balanced (see p. 107).

45 Proclus, In Parmenidem, v, 1000.26-28.

46 Steel 1997, p. 9o-91.

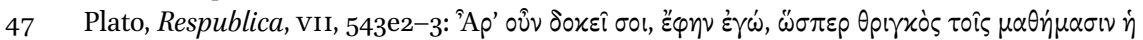

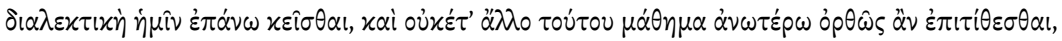

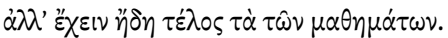

48 See Bonelli 2016 for an in-depth analysis of this passage.
} 
analogous to that between a work of geometry and the Elements of Theology. As in the previous passage, mathematics is said to deploy the four dialectical methods. More precisely, dialectic is set over mathematics contiguously, containing, in a concentrated manner, these four methods or powers that are then bestowed upon mathematics (42.13-43.1), first to the common mathematical science, and then, through it, to the various mathematical subdisciplines (44.11-14). Just as the common mathematical science is set over the particular mathematical sciences, dialectic is set over mathematics, and just as dialectic is set over mathematics, the knowledge of intellect presides over dialectic (42.13-15; 43.11-12; 44.14-23). ${ }^{49}$ In intellect itself, the four powers of dialectic are contained in a unitary manner. Likewise, its knowledge is immobile, undivided, unitary and concentrated, providing the content that is unfolded in and through dialectic ( $\sigma \nu \mu \pi \tau \dot{\sigma} \sigma \sigma \varepsilon l . . . \tau \dot{\alpha} \varsigma \dot{\alpha} \nu \varepsilon \lambda \hat{i} \xi \varepsilon ı$, 44.20) and turned into discursive

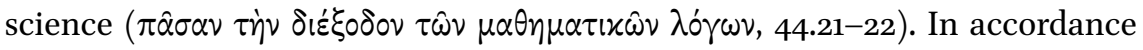
with sound Proclean principles, that which contains and causes also perfects what it engenders. Thus, intellect produces dialectic and perfects it. It is able do so because it contains, in the manner proper to itself, its powers and contents.

An excerpt from the Cratylus Commentary confirms the role of intellect in the generation of dialectic (III, 2.5-12). Here, Proclus moreover explains that division corresponds to the procession of all things from the One, that definition corresponds to the synthesising into a single circumscription of what is proper [to many things], that demonstration corresponds to the manner in which Forms are mutually present to one another, which constitutes their identity and founds their mutual difference, and that analytics corresponds to the reversion of all things to the One and to their proper principles. The four methods or powers are thus perfectly suited to explain these different structural features of reality. What is more, the fact that intellect comprehends these

49 There is thus a double analogy, and not just 'un parallèle', which should be sufficient to discard the objection put forward by Bonelli 2016, p. 402-4O3. Neither is there a real problem in the fact that dialectic seems to be treated as a faculty, more precisely the highest part of

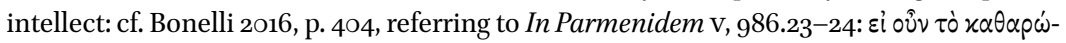

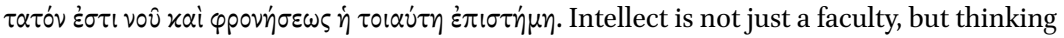
that is nothing but its object. Analogously, dialectics is not just a method, but also the direct expression of the highest rational capacity of the soul and the system of knowledge generated by it. And as it is to be expected, the image of intellect, which is dialectic, is less unified than its source and does therefore not exhibit the same degree of unity between cognition and its object. A further complication is introduced, though, by the fact that in the phrase quoted Proclus calls dialectics intellect, in what is actually a quote from the Philebus (58d6-7). Proclus in fact makes a distinction between the intellective capacity of the soul and the intellect in itself (cf. Timaeus, 28a1). For these and further refinements, see MacIsaac 2010. See also Gritti 2008, p. 182-183. 
structures and at the same time generates dialectic grounds the cogency and irrefutability of dialectic's proofs and the truth and accuracy of the knowledge it produces and in which it consists. ${ }^{50}$

\section{Dialectic Unfolding of the Truth in the Elements of Theology}

Now, let's take a closer look at the overall structure of the Elements of Theology and especially at the initial propositions and proofs. It is often thought that the Elements of Theology start with the highest principle, the One. I do not think that is accurate. "Every plurality in some way participates the one", is one way

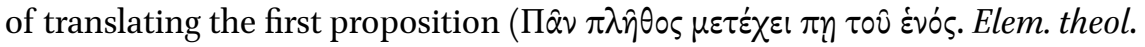
1). The reader versed in Neoplatonism will think immediately that the author must be talking about the first principle, in which everything participates. ${ }^{51}$ However, this is not the perspective a reader of a stoicheiôsis is intended to take, as a reader who abides by the rules of the literary genre is not meant to come with any preconceived ideas. Such a reader is not expected to know that the One is the highest metaphysical principle. They will perhaps understand the last two words of the proposition as meaning 'oneness' or 'unity', rather than 'the one,' and if they continue to read the proof, they will see that is what is meant. The proof takes the form of another mainstay of the genre, a reductio ad absurdum: assume that there is such a plurality that in no way partakes of unity, and you find yourself entangled in contradictions, for if there is such a plurality, that would mean that none of the parts of which it consists and none of the parts of which these parts consist would be one. Hence, a plurality would dissipate into nothingness or into an unending infinity. These consequences of our assumption are not possible, and hence the assumption is to be rejected. This may not be a very accurate rendering of the proof, yet it should be sufficient for our present purpose. ${ }^{52}$

The next two propositions deal with anything that participates (the) one, that is, participates unity. Such things are both one and not-one (prop. 2) and they become one through participation of (the) one (prop. 3). The proofs for

\footnotetext{
$5^{\circ} \quad$ Gritti 2008, p. 255-306.

51 See Onnasch and Schomakers 2015, p. XLV: "Angefangen wird mit dem Einen [...]", yet see also p. LII-LIII: "So verwendet Proklos z. B. im ersten Kapitel der Theologischen Grundlegung den Begriff des Einen (oder der Einheit) in einer These über das Verhältnis zwischen Einheit und Vielheit, er erläutert diesen Begriff selbst jedoch nicht."

$5^{2}$ I have attempted to give a more accurate reconstruction of the proofs of the first propositions in Opsomer 2013.
} 
these two propositions consist mainly in explaining what is meant by the terms used and why what is stated follows from the way in which they are used. The fourth proposition distinguishes such participants with something that is noth-

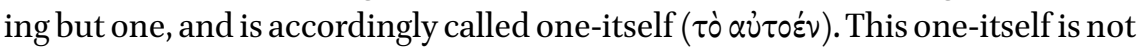
something that is something other than one, and subsequently happens to be one as well: being one is all it is, and that is exactly what the expression oneitself denotes - analogously to similar compositions with auto- already coined by Plato. The proof for the fourth proposition is based on the idea that such a one-itself really has to exist, on pain of producing a vicious regress.

The fifth proposition states that every plurality is posterior to the one-itself. This is followed by an extensive and complex proof, the details of which are not always easy to grasp. Yet it soon becomes clear that one important implication of this theorem is that there can only be one such one-itself (cf. prop. 5, 6.720 ). Hence, by the end of the fifth proposition we have reached an existing and unique one-itself, preceding all plurality and hence completely independent of anything else (because everything other than the one-itself is part of the plurality that is posterior to it). In other words, we have discovered 'the One'. The fact that a separate proof was needed in order to demonstrate that there can only be one one-itself shows that Proclus is quite capable of distinguishing two different usages of the Greek word $\tilde{v} v$ : that of unity as the lack of internal division, and that of cardinality one.

Causality is only introduced explicitly from proposition 7 onwards. Proclus argues that the relation between things participating the good and the gooditself is the same as that between the participants of the one and the one-itself. This notion of good-itself is introduced in proposition 8. Goodness is understood as that toward which things strive. Next Proclus argues that there is a first productive cause from which all things proceed (prop. 11), which is at the same time that toward which all things strive. This is 'the Good' (prop. 12), and based on the idea that "every good unifies its participant and all unification is good" Proclus concludes that the good is identical with the one. That is, the good-itself is identical with the one-itself (prop. 13), and now we have the Good or the One, the full-fledged first principle of Proclean metaphysics.

In the next two hundred or so propositions Proclus sets out, first, at the same time both the general logical principles or rules of the system and some of the basic metaphysical principles - or 'entities' - and their hierarchical order. To give an example, in proposition 2o, he develops the hierarchy One-IntellectSoul-Body, on the basis of an analysis of motion and a corresponding hierarchy of movers and moveds (prop. 14), linked with the capacity of reversion and selfreversion required for some of these movers (prop. 15-19). Later, in proposition 101, he develops finer hierarchies, such as the triad Being-Life-Intellect, but it is 
only in the second half of the work that he discusses the properties of the different classes of entities in greater detail as well as even more refined internal hierarchies. The text ends with a theorem on the (human) rational soul, which constitutes the lowest level of 'divine' or 'transcendent' reality (and incidentally also contains a stab at Plotinus, as it outright rejects the latter's theory of the undescended soul - but true to the rules of the game, Proclus does not mention his opponent). The second part of the work starts, then, from the upper realms of divine reality, the henads, and moves down to the realms of intellects and then souls, so as to end with the lowest type of soul that is still rational and autonomous. Or to use a technical term: the rational soul is self-constituted

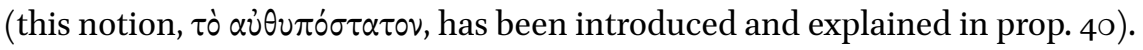
Lower realities are no longer self-constituted and self-sufficient; they are mere products of the higher causes, and hence there is no place for separate sections on them in a work on theology.

The Elements of Theology appears to conform to the general idea of a Platonic dialectic science: it deals with transcendent reality, corresponding to the upper, 'intelligible' segment of the line mentioned in Plato's famous description of dialectic (Resp. VI, 5011b2), and, on a reading that is charitable to Proclus, to the Forms situated at that level (511c2). It does so in a discursive manner, 'unfolding' the theorems one after the other. ${ }^{53}$ It demonstrates, divides kinds, specifying what is identical and what is different, and when it leads up to the causes it practices analysis. The work moreover conforms to some, though not all, essential features of the mos geometricus. Most importantly, it contains an ordered set of discrete theorems, whereby later theorems are demonstrated on the basis of the preceding ones. But what happens, one may ask, with the first theorems? Since the very first theorem cannot build on any preceding theorem, what are the starting points for its proof? In a mathematical manual, those would be axioms, postulates, hypotheses, definitions, common notions-in short, assumptions in some form or other. Since such lists are absent from Proclus' Elements of Theology — but not, remarkably, from the Elements of Physics - the author should not be allowed to appeal to any such assumptions.

53 This reading is confirmed by what is probably the earliest textual echo of Proclus' Elements of Theology, namely in two passages in pseudo-Dionysus, where the author uses

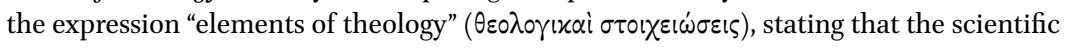

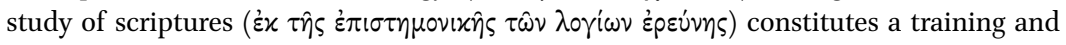
consists of the partial unfolding ( $\mu \varepsilon p \ltimes \alpha \alpha \hat{\varsigma} \varsigma \alpha \nu \varepsilon \lambda i \xi \varepsilon \sigma l)$ of divine truths: De divinis nominibus II.9, 648A-B, and III.2, 681A. See Mueller-Jourdan 2013 for ps.-Dionysius' reception of Elementatio theologica 1 . 
A closer look at the first propositions and proofs show that Proclus introduces certain very general concepts and explains what they mean and how they are related over the course of the proofs. The most crucial of these concepts are one, many, part, whole, participation, F-itself. He teases out the meaning of these words by manipulating them in his proofs. He moreover appeals to the contrariety of one and many (and since their domain is universal, they even function as contradictions), or to the notion that the whole is greater than the (proper) part. As for participation, he starts from a very general notion, for which it suffices to accept that $X$ is $F$ if $X$ participates in $F,{ }^{54}$ while leaving open the possibility that participation may be symmetric. After an argument based on the view that participation is asymmetric, he formulates what could be seen as an objection, or at least as a problem that requires further consideration, based on the assumption that participation is not asymmetric, but arguing apagogically that this cannot be correct: participation has to be antisymmetric ${ }^{55}$ (and since it is irreflexive, it turns out to be asymmetric as well). This shows that for Proclus the semantic value of 'participation' does not entail asymmetry, while as an ontological relation it must. It moreover shows that he is aware of the fact that he has not defined his key concepts, but rather needs to clarify them in the course of his argument.

Proclus neither marks any of these as assumptions, nor does he indicate that he stipulates specific meanings. What is truly remarkable, however, is the fact that he was aware that some of these propositions implicitly appealed to were used by him as undemonstrated axioms, or those derived from common notions. The idea that the whole is greater than the part, for instance, is listed in our editions of Euclid as one of the common notions and is called an axiom by Proclus in his Commentary on Euclid. ${ }^{56}$ In the Commentary on the Parmenides, while dealing with the very same issues as in the propositions that I have discussed, Proclus states that Plato uses the principle that unity and plurality are mutually exclusive as a 'common notion' ${ }^{57} \mathrm{He}$ moreover explains that this common notion is uncorrupted and indemonstrable and is used by Plato

54 ' $\mathrm{X}$ is F' is a sufficient, but not a necessary condition. There is one case in which $\mathrm{X}$ is $\mathrm{F}$ without participating in $\mathrm{F}$, namely that of the $\mathrm{X}$-itself. $\mathrm{X}$-itself can be said to be $\mathrm{F}$ (although this is not a case of normal predication), but since it is not something other than $\mathrm{F}$, it cannot be said to participate in $\mathrm{F}$ (participation is not reflexive).

See Proclus, Elementatio theologica, prop. 5, p. 4, l. 20-22 for the asymmetric (or antisymmetric) use, and p. 6, l. 7 for the symmetric use, with Opsomer 2013, p. 63o-632.

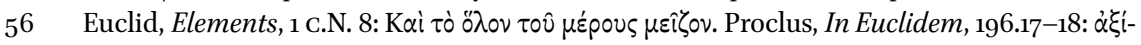

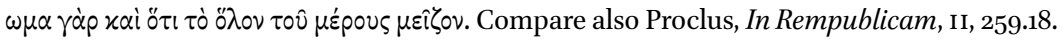

Proclus, In Parmenidem, vi, 1091.19-23. 
as a starting point for demonstrations, in accordance with the practice of the geometers. ${ }^{58}$ As for the participation relation, I have so far been unable to locate a passage in which Proclus explicitly states as an axiom that it is not symmetric. He does, however, appeal to the principle, and his successor Damascius explicitly defines it in this manner. ${ }^{59}$

So why did Proclus not make his life easier by inserting a list of common notions, definitions, and/or axioms before the first proposition? I surmise that it may have to do with his notion of dialectic. Dialectic is a supreme science that provides principles to the other sciences, ${ }^{60}$ but there is no superordinate science that can do the same for dialectic. Instead, dialectic draws its principles directly from its progenitor, intellect. These principles appear prior to the possession of any demonstrative science as conceptions that we already possess. They merely need to be explicated and articulated so as to make them useful for discursive reasoning, exactly what Proclus accomplishes in the first proofs of our text. This moreover shows that intellect has a twofold relation to dialectic: earlier we have seen that dialectic is considered to be a necessary preparation for the unitary intellective vision. Now, however, we have come to the conclusion that in addition, intellect provides certain concepts that are innate to our souls but remain untransparent or even unconscious as long as we have not articulated them by making use of discursive reason. ${ }^{61}$

Dialectic manifests itself in an even subtler manner in the structure of the Elements of Theology. As I have argued, the work does not start with the highest principle, it instead starts from plurality as a given and accounts for the conditions of its possibility. In doing so, the author makes use of certain assumptions - common notions or axioms - though not referred to as suchwhich are discursively justified. Using the language of the Republic, one could say that they are introduced as hypotheses, yet, contrary to the geometers, who are unable to account for them, ${ }^{62}$ the dialectician does justify them, but can only succeed insofar as he can tie them to a first principle. The dialectician thus moves - analytically - from empirical plurality to a first principle, which one could call—with the Republic ${ }^{63}$ and in conformity with his remarks in

\footnotetext{
$5^{8}$ Proclus, In Parmenidem, vi, 1092.15-27.

59 Proclus, In Parmenidem, vI, 1078.21-1079.1; Damascius, De principiis 3.168.11-16.

6o Proclus, In Rempublicam, I, 283.6-16.

61 On the need to articulate innate concepts, see Helmig 2012, p. 278-289. That Proclus considers dialectic, as a discursive science, to be grounded in intellect, is common knowledge among scholars of Neoplatonism. See, for instance, Beierwaltes 1965, p. 240-270.

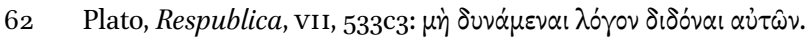

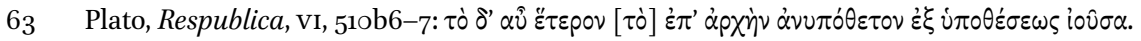


other works ${ }^{64}$ - unhypothetical. This unhypothetical principle, the One-Good, is reached and explained in propositions 4-13. Having reached this principle, the dialectician no longer has any need for the hypotheses which have served their function as stepping-stones in his way up to the unhypothetical principle. Tied to the security of this first principle, the dialectician can descend again to the intelligible Forms - not, however, to the world below it ${ }^{65}$ — without resorting to images ${ }^{66}$ in order to study them at their own level and through their mutual relations. ${ }^{67}$ This is exactly what Proclus does in the rest of the work. And indeed, he uses no diagrams, contrary to the geometers and to his own practice in the Elements of Physics. ${ }^{68}$

\section{Bibliography}

\section{Primary Sources}

Alcinous, The Handbook of Platonism, trans. J. Dillon, Oxford, Clarendon Press, 1996. Berthold of Moosburg, Expositio super Elementationem theologicam Procli. Prologus, Propositiones 1-13, eds M.R. Pagnoni-Sturlese, L. Sturlese, Hamburg, Meiner, 1984.

Damascius, Traité des premiers principes. Volume III, De la procession, eds L.G. Westerink, J. Combès, Paris, Les Belles Lettres, 1991

Dionysius the Ps.-Areopagite, De divinis nominibus, ed. B.R. Suchla, Berlin/New York, De Gruyter, 199 .

Euclid, The thirteen books of Euclid's Elements translated from the text of Heiberg with introduction and commentary, ed. T.L. Heath, 3 vol., Cambridge, Cambridge University Press, 1908. [Reprint New York, Dover, 1956].

Marinus, Proclus ou Sur le bonheur, eds H.D. Saffrey, A.-P. Segonds, Paris, Les Belles Lettres, 2001.

Nicholas of Methone, Refutation of Proclus' Elements of Theology. A critical edition with an introduction on Nicholas' life and works, ed. A. Angelou, Athens, Academy of Athens, 1984.

Ioane Petrizi, Kommentar zur Elementatio theologica des Proklos: Übersetzung aus dem

64 E.g., Proclus, In Rempublicam, I, 283.6-16; In Parmenidem, I, 623.18-19; 655.18-656.2; v, 1033.26-1034.7.

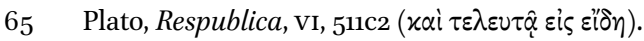

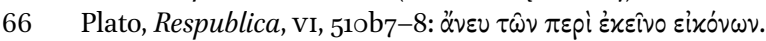

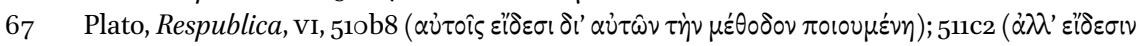

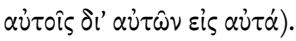

68 And moreover, contrary to modern interpreters of the work: see e.g. Dodds 1963, p. 255, 278, 282; Chlup 2012, p. 89, 96, 98, 103 . 
Altgeorgischen, Anmerkungen, Indices und Einleitung, ed. L. Alexidze, L. Bergemann, Amsterdam, 2009.

Patrizi, F., Procli Lycii Diadochi philosophi eminentissimi Elementa theologica, et physica. Opus omni admiratione prosequendum, Ferrara, 1583.

Plato, Platonis Opera, ed. J. Burnet, Oxford, Oxford University Press, 1903.

Plotinus, Traité 20, I,3: Sur la dialectique, trad. J.-B. Gourinat, Paris, Vrin, 2016.

Proclus, In Platonis Rem publicam commentarii, ed. W. Kroll, 2 vol., Leipzig, Teubner, 1899-19o1 [Reprint Amsterdam, Hakkert, 1965].

Proclus, In Platonis Cratylum commentaria, ed. G. Pasquali, Leipzig, Teubner, 1908 [Reprint Stuttgart, Teubner, 1994].

Proclus, The Elements of Theology, ed. E.R. Dodds, Oxford, Oxford University Press, 1963. Proclus, Theologische Grundlegung. Griechisch-Deutsch, ed. E.-O. Onnasch, B. Schomakers, Hamburg, Meiner, 2015.

Proclus, Théologie platonicienne, ed. H.D. Saffrey, L.G. Westerink, 6 vol. Paris, Les Belles Lettres, 1968-1997.

Proclus, A Commentary on the First Book of Euclid's Elements, translated with introduction and notes, trans. G.R. Morrow, Princeton, N.J., Princeton University Press, 1970 [Reprinted 1992].

Proclus, In Platonis Parmenidem Commentaria, Tomus I libros I-III continens, eds C. Steel, C. Macé, P. d'Hoine, Oxford, Clarendon Press, 2007.

Proclus, In Platonis Parmenidem Commentaria, Tomus II libros IV-V continens, eds C. Steel, A. Gribomont, P. d'Hoine, Oxford, Clarendon Press, 2008.

Proclus, In Platonis Parmenidem Commentaria, Tomus III libros VI-VII continens, eds C. Steel, L. Van Campe, Oxford, Clarendon Press, 2009.

Simplicius, In Aristotelis Physicorum libros quattuor priores/posteriors, ed. H. Diels, in Commentaria in Aristotelem Graeca, Vols. IX-X, Berlin, Reimer, 1882-1895.

Syrianus, In Metaphysica commentaria, in Commentaria in Aristotelem Graeca, ed. W. Kroll, Volume vi, Part i, Berlin, Reimer, 1902.

\section{Secondary Sources}

Asper, M.(2007), Griechische Wissenschaftstexte: Formen, Funktionen, Differenzierungsgeschichten, Stuttgart, Franz Steiner.

Beierwaltes, W. (1965), Proklos. Grundzüge seiner Metaphysik, Frankfurt am Main, Klostermann Vittorio.

Bonelli, M. (2016), "Proclus et la dialectique scientifique", in J.-B. Gourinat, J. Lemaire (eds), Logique et dialectique dans l'antiquite, Paris, Vrin, p. 397-421.

Burkert, W. (1959), “ztoiXeion. Eine semasiologische Studie”, in Philologus 103, p. 167197.

Chlup, R. (2012), Proclus. An Introduction, Cambridge, Cambridge University Press.

Fauquier, F. (2018). Le Parménide au miroir des platonismes: logique-ontologie-théologie, Paris, Les Belles Lettres. 
Giardina, G.R. (2010), “Considérations critiques sur la présence d'Aristote dans l'In Euclidem de Proclus”, in A. Lernould (ed.), Études sur le Commentaire de Proclus au premier livre des Éléments d'Euclide, Villeneuve d'Ascq, Presses Universitaires du Septentrion, p. 161-180.

Gritti, E. (2008), Proclo. Dialettica, anima, esegesi, Milan, LED.

Helmig, C. (2012), Forms and Concepts. Concept Formation in the Platonic Tradition, Berlin / New York, De Gruyter.

Kobusch, T. (2018), Selbstwerdung und Personalität. Spätantike Philosophie und ihr Einfluß auf die Moderne, Tübingen, Mohr Siebeck.

Lohr, C.H. (1986), "The Pseudo-Aristotelian Liber de causis and Latin Theories of Science in the Twelfth and Thirteenth Centuries", in G. Kraye, W.F. Ryan, C.B. Schmitt (eds), Pseudo-Aristotle in the Middle Ages: The Theology and Other Texts, London, Warburg Institute, p. 53-62.

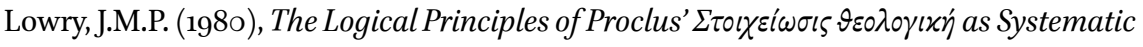
Ground of the Cosmos, Amsterdam, Rodopi.

MacIsaac, G. (2010), "Nónбıs, dialectique et mathématiques dans le Commentaire aux Éléments d'Euclide de Proclus", in A. Lernould (ed.), Études sur le Commentaire de Proclus au premier livre des Éléments d'Euclide, Villeneuve d' Ascq, Presses Universitaires du Septentrion, p. 125-138.

Martijn, M. (2014), "Proclus' Geometrical Method”, in P. Remes, S. Slaveva-Griffin (eds), The Routledge Handbook of Neoplatonism, London, Routledge, p. 145-159.

Mueller-Jourdan, P. (2013), “'Toute pluralité participe en quelque manière de l'un'. Le premier théorème des Éléments de théologie de Proclus revisité par le Pseudo-Denys l'Aréopagite", in F. Karfík, E. Song (eds), Plato Revived. Essays on Ancient Platonism in Honour of Dominic J. O'Meara, Berlin / Boston, De Gruyter, p. 41-53.

Netz, R. (1999), The Shaping of Deduction in Greek Mathematics. A Study in Cognitive History, Cambridge, Cambridge University Press.

Netz, R. (2017), "The Authority of Mathematical Expertise and the Question of Ancient Writing More Geometrico", in J. König, G. Woolf (eds), Authority and Expertise in Ancient Scientific Culture, Cambridge, Cambridge University Press, p. 374-408.

O’Meara, D.J. (1986), “Le problème de la métaphysique dans l'antiquité tardive”, in Freiburger Zeitschrift für Philosophie und Theologie 33, p. 3-22.

O'Meara, D.J. (1989), Pythagoras Revived. Mathematics and Philosophy in Late Antiquity, Oxford, Clarendon Press.

O’Meara, D.J. (2000), "La science métaphysique (ou théologie) de Proclus comme exercice spirituel”, in A.Ph. Segonds, C. Steel (eds), Proclus et la Théologie Platonicienne. Actes du Colloque International de Louvain (13-16 mai 1998). En l'honneur de H.D. Saffrey et L.G. Westerink, Leuven / Paris, Leuven University Press, p. 279290.

Opsomer, J. (2013), “Syrianus, Proclus, and Damascius”, in J. Warren, F.C.C. Sheffield 
(eds), The Routledge Companion to Ancient Philosophy, London, Routledge, p. 626642.

Opsomer, J. (2020), "Proclus' Elements of Physics and the axiomatisation of kinematics", in F. Baghdassarian, I. Papachristou, S. Toulouse (eds), Relectures néoplatoniciennes de la théologie d'Aristote, Baden-Baden, Academia, p. 83-101.

Solère, J.-L. (2003), "L'ordre axiomatique comme modèle d'écriture philosophique dans l'Antiquité et au Moyen Age", in Revue d'Histoire des Sciences 56, p. 323-345.

Steel, C. (1997), "Proclus et l' interprétation 'logique' du Parménide", in L.G. Benakis (ed.), Néoplatonisme et philosophie médiévale. Actes du Colloque international de Corfou 68 octobre 1995 organisé par la Société Internationale pour l'Étude de la Philosophie Médiévale, Turnhout, Brepols, p. 67-92. 